\title{
IMPROVEMENT OF WRITING SKILL OF PANTUN USING THE FIELDTRIP METHOD FOR ELEMENTARY SCHOOL STUDENTS
}

\author{
Aprima Vista ${ }^{1}$, Darnis Arief ${ }^{2}$ \\ 1,2 Universitas Negeri Padang, Padang, Indonesia \\ 1' $\underline{\text { avista054@gmail.com, }}{ }^{2}$ nis.darnis.@gmail.com
}

\begin{abstract}
This research is motivated by the low ability in writing Pantun for elementary school students. The purpose of this study was to determine the improvement of the ability to write pantun for elementary school students using the field trip method. This research was a classroom action research carried out in grade 5 of SDN 01 Nan Sabaris, Padang Pariaman Regency consisting of 30 students. The research procedure consisted of planning, implementing, observing, and reflecting. Data collection techniques used the method of observation, measurement of learning test results and documentation. Data analysis techniques consisted of quantitative data. Quantitative data used to analyze the results of the ability to write Pantun by measuring the percentage of mastery learning and class average. The results showed that the students' initial ability score in writing rhymes was 67.00 , cycle I got a score of 72.00, and cycle II got a score of 83.00. This research proved that there was an increase in the ability to write rhymes for elementary school students using the field trip method. The implication of this research is to be used as a reference for teachers in implementing the learning process of Pantun writing for elementary school students.
\end{abstract}

Keywords: pantun, elementary school students, field trip method

\section{PENINGKATAN KETERAMPILAN MENULIS PANTUN MENGGUNAKAN METODE KARYAWISATA UNTUK SISWA SEKOLAH DASAR}

\begin{abstract}
ABSTRAK
Penelitian ini dilatarbelakangi oleh rendahnya kemampuan menulis pantun siswa sekolah dasar. Tujuan penelitian ini adalah untuk mengetahui peningkatan kemampuan menulis pantun siswa sekolah dasar dengan menggunakan metode karyawisata. Penelitian ini merupakan penelitian tindakan kelas yang dilaksanakan dikelas V SDN 01 Nan Sabaris Kabupaten Padang Pariaman yang terdiri dari 30 siswa. Prosedur penelitian terdiri dari perencanaan, pelaksanaan, pengamatan, dan refleksi. Teknik pengumpulan data menggunakan metode observasi, pengukuran hasil tes belajar dan dokumentasi. Teknik analisis data terdiri dari data kuantitatif. Data kuantitatif untuk menganalis hasil tes kemmapuan menulis pantun dengan mengukur persentase ketuntasan belajar dan rata-rata kelas. Hasil penelitian menunjukan bahwa skor kemampuan awal siswa dalam menulis pantun yaitu 67.00, siklus I mendapatkan skor 72.00, dan siklus II mendapatkan skor 83.00. Penelitian ini membuktikan bahwa adanya peningkatan kemampuan menulis pantun siswa sekolah dasar dengan menggunakan metode karyawisata. Implikasi penelitian ini adalah untuk dapat dijadikan referensi bagi guru dalam melaksanakan proses pembelajaran menulis pantun bagi siswa sekolah dasar.
\end{abstract}

Kata Kunci: pantun, siswa sekolah dasar, metode karyawisata

\begin{tabular}{|c|c|c|}
\hline Submitted & Accepted & Published \\
\hline 11 Mei 2020 & 14 Juli 2020 & 25 Juli 2020 \\
\hline
\end{tabular}

\begin{tabular}{|l|l|l|l|l|}
\hline Citation & $:$ & $\begin{array}{l}\text { Vista, A., \& Arief, D. (2020). Improvement of Writing Skill of Pantun Using the Fieldtrip Method for Elementary School } \\
\text { Students. Jurnal PAJAR (Pendidikan dan Pengajaran), 4(4), 803-811. DOI : }\end{array}$ \\
\hline
\end{tabular}

\section{PENDAHULUAN}

Pembelajaran bahasa Indonesia merupakan pembelajaran yang wajib dibelajarkan disetiap jenjang pendidikan, termasuk jenjang sekolah dasar, (Khair,2018). Pembelajaran bahasa Indonesia menjadi wajib dibelajarkan dikarenakan bahasa Indonesia memiliki empat keterampilan yang sangat diperlukan siswa dalam proses kehidupan sehari-hari. Keempat keterampilan tersebut adalah keterampilan mendengar, berbicara, membaca dan menulis, (Mansyur, 2016). Keterampilan ini menjadi penting dikarenakan berkaitan erat dengan proses 
berbahasa dan komunikasi siswa yang akan berdampak kepada proses interaksi siswa dalam kehidupan sehari-hari.

Keempat keterampilan ini saling berkaitan antara satu dengan yang lainnya. Keterkaitan ini terjadi dan dialami oleh siswa secara teratur yaitu dimulai dari mendengar bahasa, kemudian siswa akan belajar berbicara dari apa yang didengar, belajar membaca dari apa yang dibicarakan dan belajar menulis dari apa yang telah dibaca. Artinya keterampilan bahasa indonesia ini merupakan suatu kesatuan yang dapat dipelajari. Termasuk keterampilan menulis.

Keterampilan menulis adalah salah satu keterampilan berbahasa yang bertujuan untuk menyampaikan gagasan maupun ide kedalam bentuk tulisan, (Astuti \& Mustadi, 2014). Keterampilan menulis sangat perlu dikembangkan pada siswa sekolah dasar, (Zulela, 2014). Hal ini dikarenakan keterampilan menulis berkaitan erat dengan seluruh bidang, aspek dan kegiatan seharihari. Keterampilan menulis dapat meningkatkan proses komunikasi siswa secara tidak langsung dalam menyampaikan pesan maupun informasi kedalam bentuk simpul maupun huruf (Mahendra, 2018). Maka dapat diartikan bahwa keterampilan menulis merupakan keterampilan yang dimiliki oleh siswa dalma mengungkapkan gagasan, ide, maupun buah pikiran melalui sebuah tulisan. Buah pikiran yang dimaksud dapat berupa informasi, pengetahuan, pengalaman, pendapat, perasaan maupun keinginan. Oleh sebab itu keterampilan menulis perlu diajarkan kepada siswa sekolah dasar.

Keterampilan menulis siswa sekolah dasar dapat dikembangkan salah satunya dengan menulis pantun. Pantun merupakan cara berkomunikasi dalam mengungkapkan suatu keinginan, (Wulandari et al, 2017). Pantun merupakan sebuah kebudayaan yang sudah lama ada di dalam kehidupan masyarakat, (Andriani, 2012). Pantun bagi masyarakat dahulu merupakan sebuah karya sasta yang dijadikan sebagai sarana dalam berkomunikasi antar sesama. Bahkan istilah berbalas pantun menjadi kebiasaan yang sering dilakukan oleh masyarakat zaman dahulu. Hal ini membuktikan bahwa pantun merupakan sarana yang sudah lama digunakan oleh masyarakat dalam proses komunikasi. Oleh sebab itu menulis pantun sudah seharusnya menjadi suatu kemampuan yang harus dimiliki oleh siswa sekolah dasar.

Namun berdasarkan hasil observasi yang peneliti lakukan di kelas V SDN 01 Nan Sabaris Kabupaten Padang Pariaman ditemukan fakta bahwa kemampuan menulis pantun siswa sekolah dasar masih rendah. Hal ini dikarenakan proses pembelajaran menulis pantun, siswa belajar dengan menggunakan metode ceramah yang hanya menjelaskan konsep-konsep cara menulis pantun saja tanpa diberikan penjelasan bagaimana proses menulis pantun yang seharusya. Pada kegiatan pembelajaran tersebut terlihat bahwa tidak adanya proses umpan balik berupa tanya jawab mengenai materi yang telah disajikan yang mengakibatkan banyak siswa menjadi pasif dan banyak yang tidak mengerti mengenai materi yang disampaikan. Pada obervasi tersebut terlihat bahwa siswa cendrung bosan terhadap proses pembelajaran. Analisa peneliti mengenai kebosanan ini adalah proses pembelajaran yang dilaksanakan tidak menarik siswa dan tidak memancing skemata siswa dalam mengembangkan kemampuan menulis pantunnya. Kebosanan ini juga dipengaruhi oleh tidak adanya proses pengelolaan lingkungan kelas menjadi sumber pembelajaran yang mengakibatkan siswa tidak menemukan ide dalam mengembangkan pantun. Selian itu keadaan kelas yang menjenuhkan juga berpengaruh terhadap proses menulis pantun siswa sekolah dasar yang rendah. Hal ini diperkuat dengan hasil UH yang diberikan guru kepada siswa sekolah dasar mengenai pantun dengan nilai rata-rata siswa yaitu 67.00 dengan ketuntasan klasikal yaitu sebesar $66.67 \%$. Hal ini membuktikan bahwa kemampuan menulis pantun siswa sekolah dasar berada dibawah KKM yang telah ditetapkan yaitu 75.00 dengan ketuntasan klasikal $75.00 \%$.

Dari hasil observasi terlihat bahwa adanya permasalahan yang dihadapi oleh guru dalam proses pembelajaran menulis pantun. Oleh sebab itu peneliti bersama guru kelas berdiskusi mengenai permasalahan yang terjadi didalam kelas. Hasil diskusi menyatakan bahwa adanya ketidaksesuaian proses pembelajaran dengan materi menulis pantun. Artinya materi menulis 
pantun tidak sesuai diajarkan dengan metode ceramah. Maka peneliti dan guru kelas sepakat untuk mencari solusi permasalahan tersebut kedalam bentuk penelitian tindakan kelas (PTK) dengan menemukan alternatif pembelajaran yang tepat.

Berdasarkan kajian literatur yang peneliti lakukan ditemukan bahwa metode karyawisata dapat meningkatkan keterampilan menulis (Fitriyani, 2013; Sri Retnosari, 2016; Retnosari, 2019; . Metode karyawisata merupakan sebuah proses pembelajaran yang dilakukan diluar kelas dengan membawa siswa kepada objek-objek yang berhubungan dengan proses pembelajaran, (Jumiati, 2017). Karyawisata mampu meningkatkan kemampuan menulis siswa

\section{KAJIAN TEORETIS Pantun Anak}

Pantun merupakan bagian dari puisi lama yang merupakan kebudayaan Indonesia, (Khoirotunnisa, 2018). Pantun merupakan sebuah cara mengungkapkan pikiran dan perasaan melalui susunan kata-kata yang dirangkai sehingga menjadi menarik untuk dibaca dan didengar, (Gani, 2012). Pantun merupakan sebuah upaya yang diggunakan dalam proses mendidik anak oleh bangsa Indonesia sejak dahula kala (Panjaitan \& Sundawa, 2016). Maka dapat diartikan bahwa pantun merupakan tradisi dan kebudayaan bangsa Indonesia yang bertujuan sebagai sarana dalam mendidik yang terdiri dari kata-kata yang disusun secara menarik.

Dalam proses pembuatan pantun ada beberapa karakteristik yang perlu diperhatikan yaitu pantun terdiri dariempat barus, dua baris pertama disebut dengan sampiran dan dua baris terakhir disebut dengan isi. Selain itu oantun juga terdiri dari 4 kata pada setiap baris. Pantun memiliki sajak a-b-a-b maupun a-a-a-a dan juga pantun bersifat liris romantic (Makarim et al, 2018).

Pantun memiliki banyak jenisnya. Pantun berdasarkan isinya terdiri dari pantun anak-anak, pantun orang muda, pantun orang tua, pantun jenaka dan pantun teka-teki, (Tafifin, 2017). Pada dikarenakan siswa akan belajar secara langsung melalui pemanfaatan alat indranya sehingga siswa akan mampu mengembangkan ide maupun gagasan siswa dalam proses menulis (Farhan et al, 2019). Selain itu siswa akan menemukan suasana baru yang berbeda dengan kondisi didalam kelas yang akan mengurangi kebosanan dan kejenuhan siswa sehingga akan menimbulkan keaktifan siswa dalam proses menulis (Rahmawati, 2013). Oleh sebab itu peneliti dan guru kelas sepakat untuk menggunakan metode karyawisata sebagai upaya meningkatkan keterampilan menulis siswa. Maka tujuan penelitian ini adalah untuk mengetahui peningkatkan keterampilan menulis pantun siswa sekolah dasar dengan menggunakan metode karyawisata.

penelitian ini yang akan diteliti adalah pantun anak. Pantun anak merupakan pantun yang berhubungan dengan anak-anak yang menceritakan suka maupun duka cita yang disampaikan kepada anak-anak dengan bahasa yang ringan, (Pangesti, 2015:46). Tujuan dari pantun anak ini sebagai sebuah proses yang menyenangkan dan sebagai proses pendidikan nilai dan moral.

\section{Metode Karyawisata}

Karyawisata merupakan sebuah kegiatan berupa kunjungan kesuatu tempat yang bukan berada didalam kelas dengan tujuan dari kegiatan pendidikan dan akademis, (Jumiati,2017). Karyawisata juga dapat dikatakan sebagai upaya dalam pencapaian tujuan pembelajaran dengan mengajak siswa langsung ke tempat yag berada diluar kelas yang berhubungan dengan materi yang akan dipelajari, (Rahmawati, 2013). Maka dapat diartikan bahwa karyawisata merupakan kegiatan dalam proses pembelajaran diluar kelas dengan mengunjungi objek secara langsung dalam rangka mencapai tujuan pembelajaran.

Dalam proses pembelajaran dengan menggunakan metode karya wisata ada beberapa langkah yang perlu diperhatikan. Langkah tersebut dapat dilihat pada gambar di bawah ini: 


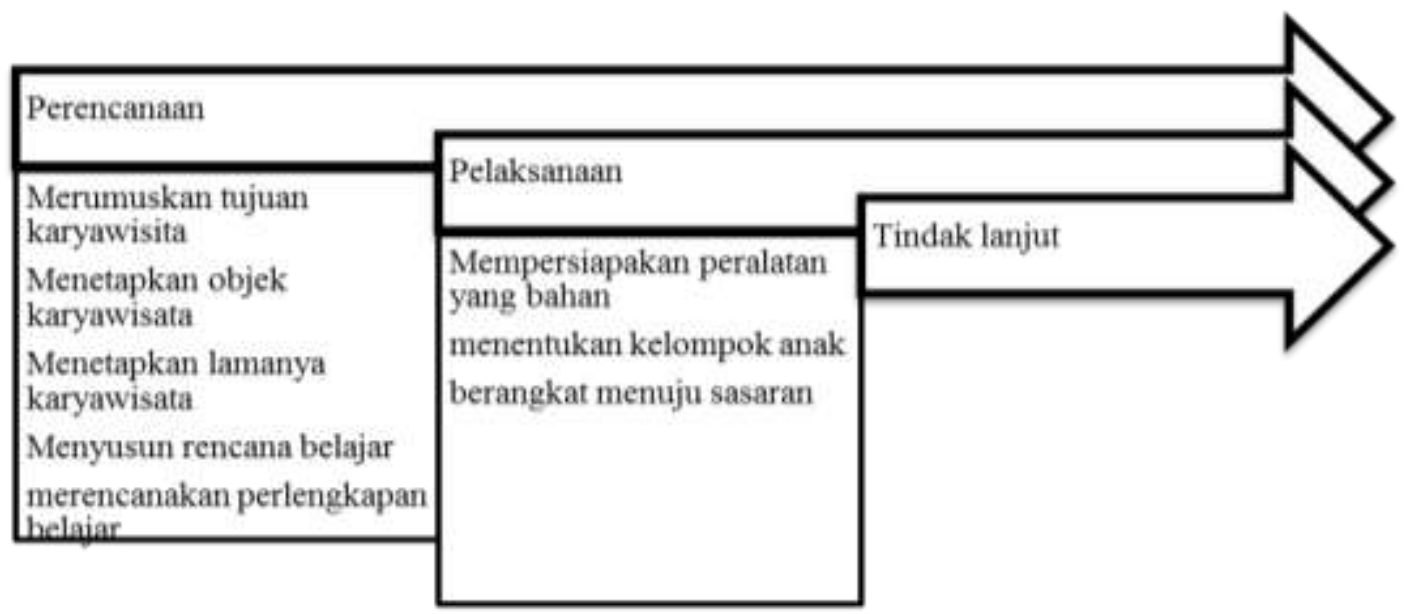

Gambar 1. Langkah Metode Karyawisata

\section{METODE PENELITIAN}

Penelitian ini dilaksanakan di kelas kelas V SDN 01 Nan Sabaris Kabupaten Padang Pariaman yang terdiri dari 30 siswa. Penelitian ini merupakan penelitian tindakan kelas (PTK). Prosedur penelitian terdiri dari perencanaan, pelaksanaan, pengamatan, dan refleksi. Pada tahap pereancanaan meliputi proses penyusunan RPP, penyusunan lembar observasi aktivitas guru, penyusunan lembar observasi aktivitas siswa dan penyusunan tes. Pada tahap pelaksanaan guru melaksanakan tindakan sesuai dengan perencanaan. Pada tahap pengamatan guru melakukan pengamatan terhadap proses pembelajaran dan hasil belajar. Pada tahapan refleksi guru dan peneliti saling berdiskusi mengenai proses tindakan yang telah dilaksanakan. Instrumen penelitian yang digunakan adalah lembar observasi, tes hasil belajar dan lembar dokumentasi.

Teknik pengumpulan data menggunakan metode observasi, pengukuran hasil tes belajar dan dokumentasi. Teknik analisis data terdiri dari data kuantitatif. Data kuantitatif untuk menganalis hasil tes kognitif dengan mengukur persentasi ketuntasan belajar dan rata-rata kelas dengan menggunakan rumus:

1. Menghitung persentase ketuntasan belajar Adapun rumus yang digunakan yaitu

$$
\mathrm{p}=\frac{\sum \text { Siswa yang tuntas belajar }}{\sum \text { Siswa }} \times 100 \%
$$

2. Menghitung nilai rata-rata

$$
P=\frac{\sum \mathrm{X}}{\sum \mathrm{N}}
$$

Keterangan

$\mathrm{X}=$ Nilai rata-rata

$\sum \mathrm{X}=$ Jumlah keseluruhan nilai

$\sum \mathrm{N}=$ Jumlah keseluruhan siswa

Perhitungan persentase dikelompokan menjadi dua bagian yaitu siswa yang mendapat nilai diatas 75 dikategorikan tuntas sedangkan nilai yang mendapatkan nilai dibawh 75 dikategorikan tidak tuntas. Adapun indikator keberhasilan PTK ini adalah keterampilan menulis pantun siswa mendapakan skor minimal 75 dengan ketuntasan belajar klasikal $75 \%$. 


\section{HASIL DAN PEMBAHASAN}

Hasil penelitian berupa keterampilan menulis pantun siswa dengan menggunakan

metode karyawisata dapat dilihat pada tabel berikut:

Tabel 1. Kemampuan Menulis Pantun Siswa

\begin{tabular}{llll}
\hline No & Siklus & Skor Rata-Rata & Ketuntasan Klasikal \\
\hline 1 & Kemampuan Awal & 67.00 & $66.67 \%$ \\
2 & Siklus I & 72.00 & $70.00 \%$ \\
3 & Siklus II & 83.00 & $83.33 \%$ \\
\hline
\end{tabular}

Berdasarkan tabel tersebut terlihat bahwa adanya peningkatan hasil kemampuan menulis siswa sekolah dasar dengan menggunakan metode karyawisata.

Langkah awal dalam penelitian ini menyusun perencanaan penelitian. Proses penyusunan perencanaan penelitian meliputi menyusun RPP, menyusun lembar observasi aktivitas guru, menyusun lembar observasi aktivitas siswa dan menyusun tes. Setelah menyusun perencanaan maka kegiatan selanjutnya adalah pelaksanaan tindakan.

Awal pelaksanaan guru memberikan salam kepada siswa dan mengkondisikan suasana dalam kelas. Kemudian guru membuka skemata siswa yang berhubungan dengan menulis pantun anak dengan cara tanya jawab. Guru membagi siswa menjadi 6 kelompok yang terdiri dari 5 siswa heterogen. Setelah siswa berkelompok guru memberikan informasi yang berhubungan dengan pantun seperti pengertian pantun dan memberikan contoh cara membaca pantun. Selain itu guru juga menjelaskan karyawisata yang akan dilaksanakan oleh siswa. Guru membimbing siswa menuju ke pantai Carocok yang merupakan salah satu pantai wisata keluarga yang berada di kabupaten Pariaman. Guru meminta siswa untuk mengamati suasana pantai tersebut. Guru memberikan informasi kepada siswa cara membuat pantun anak. Guru mengarahkan siswa untuk membuat pantun anak berdasarkan suasana pantai yang diamati. Setelah siswa membuat pantun, siswa diminta untuk membacakan hasil pantun yang telah dibuatnya. Guru meminta siswa lain untuk mengomentari hasil pantun yang telah dibuat oleh siswa lainnya. Selanjutnya guru memberikan kesempatan bertanya jawab dan meluruskan kesalahpahaman yang terjadi. Pada akhir kegiatan guru membuat kesimpulan terhadap proses pembelajran yang telah dilaksanakan.

Ketika proses pelaksanaan dilakukan maka juga dilaksanakan proses penilaian aktivitas guru dan aktivitas siswa sedangkan kemampuan menulis pantun siswa dinilai ketika siswa telah memgumpulkan pantun anak yang dibuat. Adapun hasil penilaian aktivitas guru, aktivitas siswa dan kemampuan menulis pantun anak dapat dilihat pada tabel berikut:

Tabel 2. Hasil Observasi Aktivitas Guru, Aktivitas Siswa Dan Tes Kemampuan Menulis Pantun Siklus I

\begin{tabular}{lcc}
\hline No & Pengamatan & Skor \\
\hline 1 & Aktivitas guru & 67.10 \\
2 & Aktivitas siswa & 68.42 \\
3 & Kemampuan menulis pantun & 72.00 \\
\hline
\end{tabular}

Dari tabel 2 tersebut dapat dilihat bahwa hasil kemampuan menulis pantun siswa belum mencapai indikator keberhasilan yang ditentukan. Langkah selanjutnya adalah melaksanakan refleksi terhadap hasil tersebut. Tabel tersebut menunjukan bahwa hasil kemampuan menulis pantun rendah. Rendahnya hasil ini dikarenakan tidak maksimalnya aktivitas guru sehingga berdampak kepada siswa. Dari lembar observasi terlihat beberapa temuan yang perlu diperbaiki oleh guru. 
Pada tahapan menjelaskan pengertian pantun, cara membuat pantun dan membacakan pantun guru tidak menjelaskan secara tegas sehingga siswa tidak mendengarkan penjelasan guru secara maksimal. Seharusnya guru harus mampu menyajikan materi secara tegas kepada siswa agar siswa mampu berkonsentrasi memahami informasi yang diberikan. Kemudian pada tahapan menjelaskan suasana yang berada dilingkungan karyawisata guru tidak mengarahkan siswa kepada apa saja yang perlu diamati oleh siswa sehingga siswa hanya fokus pada pantai saja. Seharusnya guru harus menjelaskan apa saja yang perlu diamati secara jelas. Selain itu hasil kemampuan menulis siswa dengan skor 72.00 dan ketuntasan klasikal hanya $70.00 \%$ membuktikan belum memenuhi indikator keberhasilan. Oleh sebab itu berdasarkan kesepakatan peneliti dan guru maka perlu dilaksanakan perbaikan pada siklus ke dua.

Siklus kedua dimulai dengan menyusun perencanaan. Proses penyusunan perencanaan penelitian meliputi menyusun RPP, menyusun lembar observasi aktivitas guru, menyusun lembar observasi aktivitas siswa dan menyusun tes. Setelah menyusun perencanaan maka kegiatan selanjutnya adalah proses pelaksanaan.

Proses pelaksanaan guru memberikan salam kepada siswa dan mengkondisikan suasana dalam kelas. Kemudian guru membuka skemata siswa yang berhubungan dengan menulis pantun anak dengan cara tanya jawab. Guru mengkondisikan siswa untuk dapay konsentrasi kepada apa yang disampaikan oleh guru. Guru membagi siswa menjadi 6 kelompok yang terdiri dari 5 siswa heterogen yang berbeda dari kelompok awal. Setelah siswa berkelompok guru memberikan informasi yang berhubungan dengan pantun seperti pengertian pantun dan memberikan contoh cara membaca pantun secara tegas. Selain itu guru juga menjelaskan karyawisata yang akan dilaksanakan oleh siswa. Guru membimbing siswa menuju ke pantai Tiram yang merupakan salah satu pantai wisata keluarga yang berada di kabupaten Pariaman. Guru meminta siswa untuk mengamati suasana pantai tersebut. Guru mengarahkan apa saja yang perlu diamati pada pantai tesebut. Guru memberikan informasi kepada siswa cara membuat pantun anak. Guru mengarahkan siswa untuk membuat pantun anak berdasarkan suasana pantai yang diamati. Setelah siswa membuat pantun, siswa diminta untuk membacakan hasil pantun yang telah dibuatnya. Guru meminta siswa lain untuk mengomentari hasil pantun yang telah dibuat oleh siswa lainnya. Selanjutnya guru memberikan kesempatan bertanya jawab dan meluruskan kesalahpahaman yang terjadi. Pada akhir kegiatan guru membuat kesimpulan terhadap proses pembelajran yang telah dilaksanakan.

Ketika proses pelaksanaan dilakukan maka juga dilaksanakan proses penilaian aktivitas guru dan aktivitas siswa sedangkan kemampuan menulis pantun siswa dinilai ketika siswa telah memgumpulkan pantun anak yang dibuat. Adapun hasil penilaian aktivitas guru, aktivitas siswa dan kemampuan menulis pantun anak dapat dilihat pada tabel berikut:

\section{Tabel 3. Hasil Observasi Aktivitas Guru, Aktivitas Siswa Dan Tes Kemampuan Menulis} Pantun Siklus II

\begin{tabular}{|c|c|c|}
\hline No & Pengamatan & Skor \\
\hline 1 & Aktivitas guru & 84.21 \\
\hline 2 & Aktivitas siswa & 88.15 \\
\hline 3 & Kemampuan menulis pantun & 83.00 \\
\hline
\end{tabular}

Dari hasil temuan tersebut maka dilaksanakan refleksi. Hasil refleksi ditemukan bahwa guru masih belum maksimal memberikan arahan terhadap apa saja yang perlu diamati oleh siswa ditempat objek wisata. Namun dari segi kuantitatif aktivitas guru, aktivitas siswa dan kemampuan menulis pantun siswa sudah mencapai indikator keberhasilan yang telah ditetapkan. Maka berdasarkan refleksi peneliti dan guru kegiatan penelitian dicukupkan sampai siklus kedua ini.

Adapun hasil penelitian secara umum dapat dilihat pada bagan berikut: 


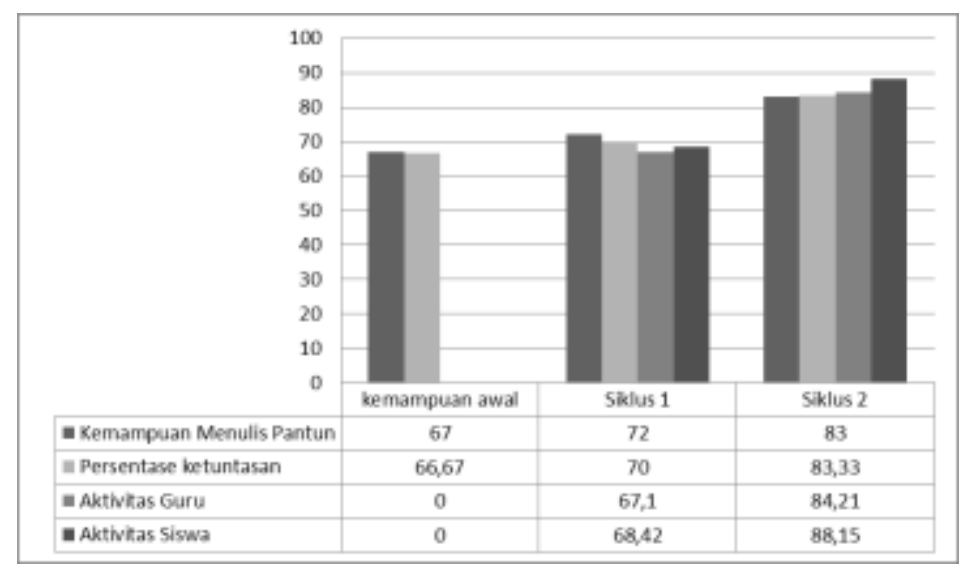

Gambar 2. Rekapitulasi Hasil Penelitian Tindakan Kelas.

Dari gambar tersebut terlihat bahwa adanya peningkatan kemampuan menulis pantun siswa sekolah dasar dengan menggunakan metode karyawisata. Peningkatan ini terjadi dikarenakan metode karyawisata memiliki kelebihan yang mampu mendukung kemampuan menulis pantun siswa berdasarkan permasalahan yang dihadapi oleh siswa.Metode karyawisata merupakan sebuah proses pembelajaran yang mengajak siswa belajar mengunjungi objek pembelajaran yang berada diluar kelas (Wondal, 2015; Mayasari \& Wikanegsih, 2019). Sehingga kebosanan yang siswa alami pada proses pembelajaran menulis pantun dapat diatasi dengan belajar secara berbeda dengan kondisi yang siswa alami biasanya. Selain itu pada penelitian ini siswa dapat berkerja secara kelompok maupun individu dengan cara menghayati lingkungan tempat belajar. Proses ini lah yang mampu mengembangkan suasana belajar yang berbeda yang mampu meningkatkan kemampuan menulis pantun siswa. Hal ini selaras dengan karakteristik karya wisata yang menyatakan bahwa pembelajaran dengan karyawisata dapat dilakukan secara individu maupun kelompok dengan membawa siswa kepada suasana langsung pembelajaran

\section{SIMPULAN DAN REKOMENDASI}

Hasil penelitian menunjukan bahwa skor rata-rata kemampuan awal siswa dalam menulis
(Nashruddin, 2015; Putra, 2017). Selain itu siswa belajar dengan karyawisata dapat belajar secara langsung dari lingkungan yang berhubungan dengan materi yang akan disajikan. Proses ini lah membuat siswa merasakan belajar secara nyata sehingga siswa mudah memahami informasi yang disampaikan. Hal ini selaras dengan proses pembelajaran karyawisata yang membawa siswa ketempat objek informasi secara langsung, (Habibi, 2016; Permatasari \& Wikanengsih, 2018). Selain itu pada penelitian ini siswa dibawa untuk dapat mengamati keadaan lingkungan yang ada disekitar. Hal ini akan mampu mempermudah siswa untuk memahami proses pembelajaran secara langsung. Hal ini juga sesuai dengan proses pembelajaran karyawisata yang menuntut siswa untuk mengamati keadaan sekitar (Ridho, 2019). Selain itu penelitian ini juga dapat merangsang kreativitas siswa dalam menulis pantun. Hal ini ini sesuai dengan karakteristik metode karyawisata yang mampu meningkatkan kreativitas siswa, (Pangastuti \& Qumillaila, 2017). Hal ini lah yang menjadi landasan terjadinya peningkatkan kemampuan menulis pantun untuk siswa sekolah dasar dengan menggunakan metode karyawisata.

pantun yaitu 67.00, siklus I mendapatkan skor ratarata sebesar 72.00, dan siklus II mendapatkan skor 
rata-rata sebesar 83.00. Hasil penelitian ini menyimpulkan bahwa adanya peningkatan kemampuan menulis pantun siswa sekolah dasar dengan menggunakan metode karyawisata. Peneliti memberikan rekomendasi kepada peneliti selanjutnya agar dapat mempersiapkan secara baik proses karyawisata siswa meliputi proses

\section{DAFTAR PUSTAKA}

Andriani, T. (2012). Pantun Dalam Kehidupan Melayu (Pendekatan historis dan antropologis). Sosial Budaya, 9(2), 195211.

Astuti, Y. W., \& Mustadi, A. (2014). Pengaruh Penggunaan Media Film Animasi terhadap Keterampilan Menulis Karangan Narasi Siswa Kelas V SD. Jurnal Prima Edukasia, 2(2), 250-262.

Farhan, A., Martha, I. N., \& Putrayasa, I. B. (2019). Peningkatan Kemampuan Siswa Menulis Teks Negosiasi Dengan Menggunakan Metode Karyawisata Kelas $\mathrm{X}$ Ipa 1 Man 1 Buleleng. Jurnal Pendidikan Bahasa dan Sastra Indonesia Undiksha, 8(2), 1-10.

Fitriyani, I. N. (2013). Peningkatan Keterampilan Menulis Laporan Pengamatan melalui Metode Karya Wisata Siswa Sekolah Dasar. Jurnal Penelitian Pendidikan Guru Sekolah Dasar, 1(2), 1-10.

Gani, E. (2012). Kajian Terhadap Landasan Filosofi Pantun Minangkabau. Komposisi: Jurnal Pendidikan Bahasa, Sastra, dan Seni, 10(1), 1-10.

Habibi, N. U. F. (2016). Peningkatan Keterampilan Menulis Laporan Perjalanan Melalui Metode Karyawisata. Jurnal Pendidikan Bahasa dan Sastra Indonesia, 5(1), 1-10.

Jumiati, J. (2017). Penerapan Metode Karya Wisata pada Konsep Dasar IPA MI/SD Materi Perkembangbiakan untuk Meningkatkan Motivasi Belajar Mahasiswa PGMI. Muallimuna: Jurnal Madrasah Ibtidaiyah, 2(2), 19-27.

Khair, U. (2018). Pembelajaran Bahasa Indonesia dan Sastra (BASASTRA) di SD dan keamanan, transportasi , konsumsi dan jadwal. Hal ini agar guru maupun penelit lainnya tidak kewalahan dalam membawa siswa saat karyawisata. Penelitian ini merekomendasikan agar guru dapat menggunakan metode karyawisata untuk meningkatkan kemampuan menulis pantun siswa sekolah dasar.

MI. AR-RIAYAH: Jurnal Pendidikan Dasar, 2(1), 81-93.

Khoirotunnisa, R. P., Hasanah, M., \& Dermawan, T. (2018). Pengembangan Bahan Ajar Menulis Pantun Bermuatan Nilai Budaya dengan Strategi Pohon Kata untuk Siswa Kelas VII. Jurnal Pendidikan: Teori, Penelitian, dan Pengembangan, 3(2), 238244.

Mahendra, D. (2018). Pengaruh Penggunaan Video Pembelajaran terhadap Keterampilan Menulis Narasi Siswa Kelas V SDN Wiyung 1/453 Surabaya. Jurnal Penelitian Pendidikan Guru Sekolah Dasar, 6(1), 1-10.

Makarim, H., Holipah, S., \& Helmi, H. (2018). The Development Book OF Story Based Sundanese Culture as Media on Indonesian Language with Pantun Material in IV Class Elementary School. DIDAKTIKA TAUHIDI: Jurnal Pendidikan Guru Sekolah Dasar, 5(1), 7082.

Mansyur, U. (2016). Inovasi Pembelajaran Bahasa Indonesia melalui Pendekatan proses. RETORIKA: Jurnal Bahasa, Sastra, dan Pengajarannya, 9(2), 1-10.

Mayasari, D., \& Wikanengsih, W. (2019). Pembelajaran Menulis Teks Puisi dengan Metode Circ pada Kelas VIII SMPN 1 Teluk Jambe Karawang. Parole (Jurnal Pendidikan Bahasa dan Sastra Indonesia), 2(2), 219-222.

Nashruddin, M. D. (2015). Penerapan Metode Karya Wisata untuk Meningkatkan Keterampilan Menulis Deskripsi pada Siswa Sekolah Dasar. Jurnal Penelitian 
Jurnal PAJAR (Pendidikan dan Pengajaran)

Volume 4 Nomor 4 Juli 2020 | ISSN Cetak : 2580 - 8435 | ISSN Online : 2614 - 1337

DOI : http://dx.doi.org/10.33578/pir.v4i2.8019

Pendidikan Guru Sekolah Dasar, 1(2), 18.

Pangastuti, R., \& Qumillaila, Q. (2017). Pengaruh Metode Karyawisata Terhadap Kreativitas Menggambar Anak di Taman KanakKanak Bani Toifur Kabupaten Nganjuk. AL-ATHFAL: JURNAL PENDIDIKAN ANAK, 3(2), 169-184.

Pangesti, M. D. (2015). Buku Pintar Pantun dan Peribahasa Indonesia. Jakarta: Lembar Langit Indonesia.

Panjaitan, L. M., \& Sundawa, D. (2016). Pelestarian Nilai-Nilai Civic Culture dalam Memperkuat Identitas Budaya Masyarakat: Makna Simbolik Ulos dalam Pelaksanaan Perkawinan Masyarakat Batak Toba di Sitorang. Journal of Urban Society's Arts, 3(2), 64-72.

Permatasari, D., \& Wikanengsih, W. (2018). Pengaruh Metode Karyawisata (Field Trip) Terhadap Kemampuan Menulis Teks Puisi pada Siswa Kelas X SMK Negeri 2 Karawang Tahun Ajaran 2017/2018. Parole (Jurnal Pendidikan Bahasa dan Sastra Indonesia), 1(5), 821828.

Putra, Y. S., Kartiko, H. D., \& Fitria, I. (2017, December). Penerapan Metode Karya Wisata Dalam Menulis Cerpen Siswa Kelas VIII SMP. In Seminar Nasional Pendidikan Bahasa Indonesia (Vol. 1, No. 1), pp. 34-48.

Rahmawati, D. L. (2013). Penerapan Metode Karyawisata dalam Pembelajaran Menulis Karya Sastra (Cerpen). Anterior Jurnal, 13(1), 43-51.

Retnosari, D. S., \& Damayanti, M. I. Penerapan Metode Karya Wisata untuk Meningkatkan Keterampilan Menulis Eksposisi Siswa Kelas V di Sekolah Dasar. (2019). Jurnal Penelitian Pendidikan Guru Sekolah Dasar, 3(2), 110.

Ridho, H., Nurjanah, N., \& Kuswari, U.(2019). Metode Karya Wisata Dalam Pembelajaran Menulis Sajak. Lokabasa, 9(2), 133-141.

Sri Retnosari, D. (2016). Penerapan Metode Karya Wisata Untuk Meningkatkan Keterampilan
Menulis Eksposisi Siswa Kelas V Di Sekolah Dasar. Jurnal Penelitian Pendidikan Guru Sekolah Dasar, 3(2), 110.

Tafifin, M. (2017). Kemampuan Menulis Pantun Siswa Kelas VII SMP Negeri 52 Konawe Selatan. Jurnal Humanika, 3(15), 1-10.

Wiyanto, A. (2012). Panduan Karya Tulis Guru. Yogyakarta: Galangpress Publisher.

Wondal, R. (2015). Meningkatkan Kemampuan Bercerita Anak Melalui Metode Karya Wisata. Jurnal Pendidikan Usia Dini, 9(1), $1-14$.

Wulandari, D., Susetyo, S., \& Amrizal, A. (2017). Pelaksanaan Pembelajaran Menulis Teks Pantun Pada Siswa Kelas VII SMPN 3 Kota Bengkulu Tahun Pelajaran 2016/2017. Jurnal Ilmiah KORPUS, 1(1), 22-31.

Zulela, M. S. (2014). Pendekatan Kontekstual Dalam Pembelajaran Menulis Di Sekolah Dasar (Action Research Di Kelas Tinggi Sekolah Dasar). Mimbar Sekolah Dasar, 1(1), 83-91. 